\title{
ANALISIS PAJAK PENGHASILAN PASAL 23 ATAS JASA FREIGHT FOWARDING PADA PT. ENERGY LOGISTICS CABANG MANADO
}

\author{
Enrico Akerina $^{1}$, Jantje J. Tinangon ${ }^{2}$, Lidia M. Mawikere ${ }^{3}$ \\ ${ }^{123}$ Fakultas Ekonomi dan Bisnis, Jurusan Akuntansi, Universitas Sam Ratulangi, Jl.Kampus Bahu, Manado, \\ 95115, Indonesia \\ E-mail : Enricoakerina@gmail.com
}

\begin{abstract}
This study discusses the Income Tax Article 23 withholding treatment of a series of transactions conducted by the Freight forwarding . the authors conducted an analysis of the suitability of the practice of withholding tax by Act No. 36 of 2008. Results of this analysis will eventually be recommended to the PT. Energy Logistics so as not to make a mistake in the determination of article 23, particularly in Freight forwarding service activities, since not all of these activities subject to Income Tax Article 23. At the PER178/PJ/2006, stated that the services of Freight forwarding is the object of withholding income tax article 23, while according to the latest regulations PER70/PJ/2007, Freight forwarding services not subject to withholding income tax article 23, but there are some services that a positive list of Income Tax Article 23 refers to the object on which PER-70/PJ/2007 such as storage services, brokerage services, packing services, pest control services are mostly done by Freight forwarding. This gives rise to multiple interpretations for implementers and users Freight forwarding services over a series of Freight forwarding services because of the uncertainty between the two rules.
\end{abstract}

Keywords : Object list Positive article 23 of Income Tax, Freight Forwarding

\section{PENDAHULUAN}

\subsection{Latar Belakang}

Perkembangan suatu negara dapat diukur dari kemandirian negera tersebut melaksanakan dan membiayai pembangunan sendiri. Dalam membiayai pembangunan, pajak mempunyai kontribusi besar terhadap penerimaan Anggaran Pendapatan dan Belanja Negara. Pajak sebagai salah satu sumber penerimaan negara terus dipacu agar menjadi primadona penerimaan negara dalam Anggaran Pendapatan dan Belanja Negara (APBN). Kontribusi pajak dalam mendanai pengeluaran negara terus meningkat membutuhkan dukungan berupa peningkatan kesadaran masyarakat wajib pajak untuk memenuhi kewajibannya secara jujur dan bertanggung jawab.

Sektor pajak yang diberlakukan di Indonesia diantaranya adalah pajak penghasilan yang juga merupakan kontribusi terbesar dalam penerimaan pajak dalam negeri. Setiap tahun setelah tahun pajak berakhir, para wajib pajak akan memenuhi kewajibannya mengisi dan menyampaikan Surat Pemberitahuan Tahunan. Pajak penghasilan sudah beberapa kali mengalami perubahan undang- undang untuk meningkatkan fungsi dan peranan perpajakan dalam rangka mendukung kebijakan pembangunan nasional. Ketentuan mengenai hal tersebut diatur dalam Peraturan Menteri Keuangan Nomor 244/PMK.03/2008 tentang Jenis Jasa Lain, sebagaimana dimaksud dalam Pasal 23 Ayat (1) Huruf c Angka 2 undang-undang Nomor 7Tahun 1983 tentang Pajak Penghasilan yang telah diubah terakhir dengan UndangUndang Nomor 36 Tahun 2008.

Pajak Penghasilan Pasal 23 (PPh Pasal 23) merupakan pajak yang dipotong atas penghasilan yang diterima atau diperoleh wajib pajak dalam negeri serta bentuk usaha tetap dengan nama dan dalam bentuk apapun yang berasal dari modal, penyerahan jasa, atau 
penyelenggaraan kegiatan selain yang telah dipotong $\mathrm{PPh}$ Pasal 21; meliputi dividen, royalti, hadiah dan penghargaan, sewa, penghasilan sehubungan dengan penggunaan harta, dan imbalan jasa tertentu.

Jasa freight forwarding atau dikenal dengan istilah jasa pengurusan transportasi atau disingkat JPT bertujuan untuk mempercepat proses transportasi sehingga barang dapat terkirim dengan waktu yang diinginkan dan kondisi barang aman dan tidak rusak. Kegiatan jasa freight forwarding ini merupakan kegiatan usaha yang memberikan pelayanan mulai penerimaan barang, penyimpanan barang, sortasi barang, pengepakan barang, penandaan barang, pengukuran barang, penimbangan barang, pengurusan penyelesaian dokumen, penerbitan dokumen angkutan, perhitungan transportasi luar negeri. Biasanya sistem pembayarannya bersifat reimbursement dimana forwarder membuat tagihan kepada konsumen (pemilik barang) yang rinciannya tergantung jenis jasa apa saja yang akan diberikan forwarder kepada konsumen.

PT. Energy Logistics merupakan salah satu contoh perusahaan yang bergerak dalam jasa freight forwarding.Permasalahan yang sering terjadi adalah timbulnya perbedaan pendapat antara pihak PT. Energy Logistics sebagai pemberi jasa dengan customer sebagai penerima jasa mengenai pemotongan PPh pasal 23 untuk jasa - jasa tertentu. Hal ini dapat mengakibatkan kerugian kepada PT.Energy Logistics.

\subsection{Tujuan Penelitian}

Tujuan melakukan penelitian ini untuk mengetahui kesesuaian pemotongan pajak penghasilan pasal 23 atas jasa freight forwarding pada PT. Energy Logostics dengan UndangUndang Nomor 36 Tahun 2008.

\section{TINJAUAN PUSTAKA}

\subsection{Akuntansi Perpajakan}

Menurut Waluyo (2013:35) Akuntasi pajak (tax accounting), menjelaskan bahwa dalam menetapkan besarnya pajak terutang tetap mendasarkan laporan keuangan yang disusun oleh perusahaan, mengingat dalam ketentuan perundang-undangan perpajakan terdapat aturan-aturan khusus yang berkaitan dengan akuntansi, yaitu masalah konsep transaksi dan peristiwa keuangan, metode pengukurannya, serta pelaporannya yang ditetapkan dengan undang-undang

\subsection{Konsep Dasar Pajak}

Menurut Undang-Undang Pajak Nomor 28 tahun 2007 tentang ketentuan dan tata cara perpajakan menyatakan pajak adalah kontribusi wajib kepada negara yang bersifat memaksa berdasarkan Undang-undang, dengan tidak mendapatkan imbalan secara langsung dan digunakan untuk keperluan negara demi kemakmuran dan kesejahteraan rakyat. Sedangkan Menurut Thomas (2013:3), pajak adalah iuran masyarakat kepada negara (yang dapat dipaksakan) yang terutang bagi yang wajib membayarnya menurut peraturan umum undangundang dengan tidak mendapat prestasi kembali yang langsung dapat ditujukan dan gunanya adalah untuk membiayai pengeluaran-pengeluaran umum yang berhubungan dengan tugas negara untuk menyelenggarakan pemerintahan.

Sejalan dengan pemikiran diatas, tampak bahwa pajak merupakan sumber pendapatan pemerintah dimana individu dan bekerja sama badan-badan yang wajib diharuskan membayar proporsi tertentu dari pendapatan mereka kepada pemerintah untuk program (Akinleye \&Ogunmakin, 2016). 


\subsection{Pengertian Pajak Penghasilan}

(Mardiasmo 2013:155), menyatakan bahwa sesuai dengan sebutannya pajak penghasilan itu dikenakan atas penghasilan. Pajak penghasilan merupakan salah satu jenis pajak pusat yang obyeknya adalah penghasilan.Pajak penghasilan dikenakan terhadap wajib pajak yaitu apabila telah terpenuhi syarat subyektif dan syarat obyektif sebagamaina ditentukan oleh Undang-Undang Pajak Penghasilan.Menurut UU Nomor 28 Tahun 2009 Tentang Pajak Daerah dan Retribusi Daerah, yang dimaksud dengan Pajak Daerah adalah "Pajak Daerah, yang selanjutnya disebut Pajak, adalah kontribusi wajib kepada Daerah yang terutang oleh orang pribadi atau badan yang bersifat memaksa berdasarkan undang-undang, dengan tidak mendapatkan imbalan secara langsung dan digunakan untuk keperluan Daerah bagi sebesar-besarnya kemakmuran rakyat".

\subsection{Dasar Hukum Pajak Penghasilan}

Peraturan perundang-undangan yang mengatur pajak penghasilan di Indonesia adalah UU No. 7 Tahun 1983 yang telah disempurnakan dengan UU No. 7 Tahun 1991, UU No. 10 Tahun 1994, UU No. 17 Tahun 2000, UU No.36 Tahun 2008, Peraturan Pemerintah, Keputusan Presiden, Keputusan Menteri Keuangan, Keputusan Direktur Jenderal Pajak maupun Surat Edaran Direktur Jenderal Pajak

\subsection{Pajak Penghasilan Pasal 23}

Menurut (Waluyo, 2013 : 184), Pajak Penghasilan Pasal 23 adalah pajak penghasilan yang dipotong atas penghasilan yang diterima atau diperoleh Wajib Pajak dalam negeri dan Bentuk Usaha Tetap yang berasal dari modal, penyerahan jasa, atau hadiah dan penghargaan, selain yang telah dipotong PPh Pasal 21. Supramono dan Damayanti (2010:85) menegaskan bahwa PPh Pasal 23 adalah pajak yang dipotong atas penghasilan yang diterima atau diperoleh wajib pajak dalam negeri (orang pribadi atau badan), serta bentuk usaha tetap dengan nama dan dalam bentuk apa pun yang berasal dari modal, penyerahan jasa, atau penyelenggaraan kegiatan selain yang telah dipotong PPh Pasal 21, meliputi dividen, royalti, hadiah dan penghargaan, sewa, penghasilan sehubungan dengan penggunaan harta, dan imbalan jasa tertentu.

\subsection{Subjek Pajak Penghasilan Pasal 23}

Subjek pajak diartikan sebagai orang yang dituju oleh undang - undanguntuk dikenakan pajak. Pajak Penghasilan dikenakan terhadap Subjek Pajakberkenaan dengan penghasilan yang diterima atau diperolehnya dalam masapajak.Subjek Pajak atau penerima penghasilan yang dipotong Pajak PenghasilanPasal 23 adalah Wajib Pajak baik Wajib Pajak Orang Pribadi maupun Wajib PajakBadan, dan Bentuk Usaha Tetap.Wajib pajak orang pribadi sebagai subjek pajak dapat bertempat tinggalatau berada di Indonesia ataupun di luar Indonesia. Subjek pajak yang bertempat tinggal di Indonesia disebut subjek pajak dalam negeri. Subjek pajak dalam negeri adalah orang pribadi yang bertempat tinggal di Indonesia atau orang pribadi yang berada di Indonesia lebih dari 183 hari dalam jangka waktu 12 bulan, atau orang pribadi yang dalam suatu tahun pajak berada di Indonesia dan mempunyai niat untuk bertempat tinggal di Indonesia. Sedangkan subjek pajak yang bertempat tinggal di luar Indonesia disebut subjek pajak luar negeri. Subjek pajak luar negeri adalah orang pribadi yang tidak bertempat tinggal di Indonesia atau berada di Indonesia tidak lebih dari 183 hari dalam jangka waktu 12 bulan.

\subsection{Jasa Freight Fowarding}

Pengertian jasa freight forwarding pernah didefinisikan dalam Peraturan Menteri Perhubungan Nomor PER-178/PJ/2006 (yang kemudian dicabut dengan terbitnya PER- 
70/PJ/2007) dengan mengacu pada Keputusan Menteri Perhubungan Nomor KM/10 Tahun 1988 tentang Jasa Pengurusan Transportasi. Berdasarkan Keputusan Menteri Perhubungan tersebut, yang dimaksud dengan jasa freight forwarding adalah usaha yang ditujukan untuk mewakili kepentingan pemilik barang untuk mengurus semua kegiatan yang diperlukan bagi terlaksananya pengiriman dan penerimaan barang melalui transportasi darat, laut, dan udara yang dapat mencakup kegiatan penerimaan, penyimpanan, sortasi, pengepakan, penandaan pengukuran, penimbangan, pengurusan penyelesaian dokumen, penerbitan dokumen angkutan, klaim asuransi atas pengiriman barang, serta penyelesaian tagihan dan biaya-biaya lainnya berkenaan dengan pengiriman barang-barang tersebut sampai dengan diterimanya barang oleh yang berhak menerimanya.

Dalam praktiknya, sebagian dari kegiatan operasional tersebut ada yang dilakukan sendiri oleh pihak forwarder (dengan menggunakan sarana dan prasarana milik sendiri atau sewaan) dan ada pula yang menggunakan jasa-jasa dari pihak ketiga yang memiliki sarana dan prasarana yang lebih lengkap dan memadai. Apabila tagihan (invoice) atas imbalan kegiatan operasional tersebut dilakukan secara menyatu, maka seluruh imbalan atas jasa-jasa operasional tersebut semestinya tidak dipotong PPh Pasal 23. Akan tetapi, jika tagihannya dilakukan secara terpisah (di-breakdown), sebagian dari tagihan tersebut dapat menjadi objek pemotongan PPh Pasal 23.

\section{METODE PENELITIAN}

\subsection{Jenis Penelitian}

Penelitian ini menggunakan penelitian deskriptif. Penelitian deskriptif merupakan jenis penelitian yang tujuannya untuk menyiapkan gambaran lengkap mengenai setting social atau hubungan antara fenomena yang diuji. Metode deskriptif yaitu metode yang digunakan untuk menggambarkan atau menganalisis suatu hasil penelitian tetapi tidak digunakan untuk menggunakan kesimpulan yang lebih luas (Sugiyono 2012:21)

\subsection{Tempat dan Waktu Penelitian}

Penelitian untuk skripsi ini berlangsung pada PT. Energy Logistics cabang kota Manado, yang beralamat di ruko Grand Kawanua City Walk blok c nomor 10, Adapun waktu penelitian di mulai dari bulan Juni 2017 sampai Juli 2017

\section{3. $\quad$ Metode analisis}

Metode analisis yang digunakan dalam penelitian ini adalah metode analisis deskriptif. Metode analisis deskriptif merupakan metode yang digunakan untuk menggambarkan dan menganalisis suatu hasil penelitian tetapi tidak digunakan untuk membuat kesimpulan yang lebih luas (Sugiyono, 2012: 21). Dalam penelitian ini metode analisis deskriptif yang akan diterapkan untuk mengenalisis pajak penghasilan pasal 23 atas jasa Freight Fowarding pada PT. Energy Logistics 


\section{HASIL ANALISIS DAN PEMBAHASAN \\ 4.1. Hasil analisis}

Daftar Nilai Objek Pajak Penghasilan Pasal 23 PT. Energy Logistics Cabang Manado

Tahun 2015

\begin{tabular}{|c|c|c|c|c|c|c|c|c|c|c|c|c|c|c|c|}
\hline \multirow{2}{*}{ No } & \multirow{2}{*}{$\begin{array}{c}\text { Nama } \\
\text { Perusahaan }\end{array}$} & \multirow{2}{*}{ Jenis Jasa } & \multicolumn{12}{|c|}{ Nilai Objek Pajak } & \multirow{2}{*}{$\begin{array}{c}\text { Jumlah } \\
\text { Nilai Objek } \\
\text { Pajak }\end{array}$} \\
\hline & & & Januari & Februari & Maret & April & Mei & Juni & Juli & Agustus & September & Oktober & November & Desember & \\
\hline 1 & $\begin{array}{l}\text { PT. Meratus } \\
\text { Line }\end{array}$ & $\begin{array}{c}\text { Jasa } \\
\text { Pengiriman } \\
\text { Barang }\end{array}$ & 39.478 .900 & 27.338 .400 & 9.898 .250 & 6.249 .376 & 3.225 .000 & 1.353 .000 & & & & & 650.000 & 3.190 .000 & 91.382 .926 \\
\hline 2 & $\begin{array}{l}\text { PT. Pelindo } \\
\text { IV }\end{array}$ & $\begin{array}{c}\text { Jasa } \\
\text { Penyimpanan } \\
\text { Barang }\end{array}$ & & & & 31.347 .735 & & & 1.610 .200 & 1.681 .400 & & 30.000 .000 & 63.875 .301 & & 128.514 .636 \\
\hline 3 & $\begin{array}{l}\text { PT. Pelindo } \\
\text { IV }\end{array}$ & $\begin{array}{c}\text { Jasa Penarikan } \\
\text { Kapal }\end{array}$ & 6.360 .000 & 21.674 .000 & 69.833 .000 & 7.270 .187 & 900.000 & 1.700 .000 & & & & & & & 111.137 .187 \\
\hline 4 & $\begin{array}{l}\text { PT. Lantas } \\
\text { Forwarding } \\
\text { Indonesia }\end{array}$ & Jasa Cleaning & & & & & & & 34.864 .500 & & 47.089 .500 & 24.252 .500 & & 2.880 .015 & 109.086 .515 \\
\hline 5 & $\begin{array}{c}\text { CV. Tirta } \\
\text { Raya }\end{array}$ & $\begin{array}{c}\text { Jasa } \\
\text { Pengangkutan } \\
\text { Transportasi } \\
\text { darat }\end{array}$ & & 74.000 .000 & 6.421 .090 & 12.085 .000 & & 58.750 .000 & 17.000 .000 & 600.000 & 7.855 .000 & 19.885 .000 & 15.290 .000 & 30.500 .000 & 242.386 .090 \\
\hline 6 & $\begin{array}{c}\text { PT. Bosowa } \\
\text { Berlian } \\
\text { Motor }\end{array}$ & $\begin{array}{c}\text { Jasa } \\
\text { Perawatan dan } \\
\text { Perbaikan }\end{array}$ & & & & & & & 3.358 .350 & & 4.103 .928 & & & & 7.462 .278 \\
\hline
\end{tabular}

Sumber : PT. Energy logistics Cabang Manado, 2015

Perhitungan PPh pasal 23 Atas Jasa Freight Fowarding

PT. Energy Logistics Cabang Manado

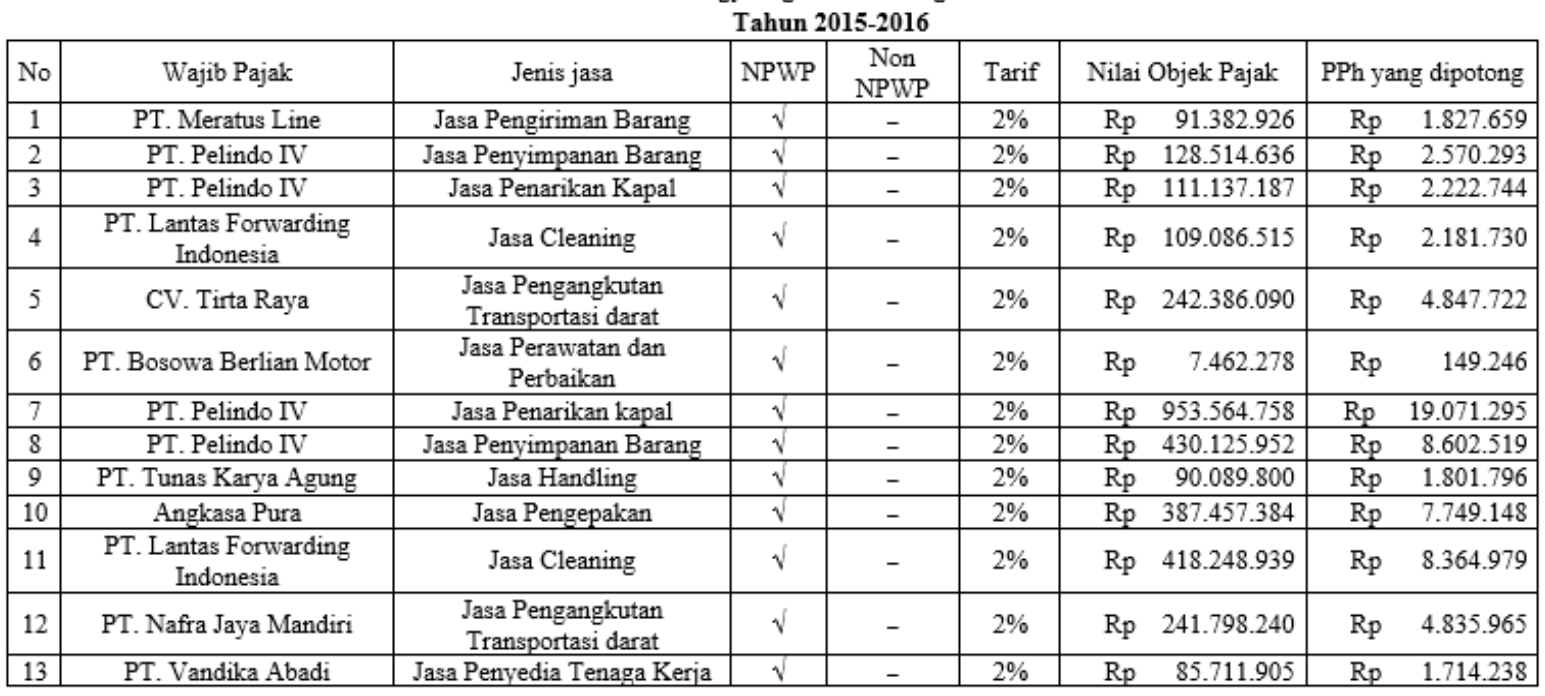

Sumber : PT. Energy logistics Cabang Manado (data diolah)

Sesuai peraturan pajak maka PT. Energy Logistics melakukan pemotongan pembayaran sebesar $2 \%$ untuk perusahaan yang memiliki NPWP dan $4 \%$ untuk perusahaan yang tidak memiliki NPWP, seperti yang akan dijelaskan dengan nilai objek pajak dan jenis-jenis jasa freight fowarding pada PT. Energy Logistics cabang Manado untuk bulan Januari sampai dengan Desember tahun 2015 dan tahun 2016

\subsection{Pembahasan}

Pada tahun 2015 PT Energy Logistics menggunakan jasa pengiriman barang dari PT. Meratus Line dengan nilai objek pajak yang harus dipotong sebesar Rp. 91.382.926, PT 
Energy Logistics menggunakan jasa penyimpanan barang dari PT. Pelindo IV dengan nilai objek pajak yang harus dipotong Rp. 128.514.636 dan untuk jasa penarikan kapal jumlah nilai objek pajaknya yang harus dipotong sebesar Rp. 111.137.187, PT. Energy Logistics menggunakan jasa cleaningdari PT. Lantas Fowarding dengan nilai objek pajak yang harus dipotong sebesar Rp. 109.086.515, PT. Energy Logistics menggunakan jasa pengangkutan transportasi darat dari CV. Tirta Raya dengan jumlah nilai objek pajak yang harus dipotong sebesar Rp. 242.386.090, dan PT. Energy Logistics menggunakan jasa dari PT. Bosowa Berlian Motor dengan jasa perawatan dan perbaikan dengan jumlah nilai objek pajaknya yang dipotong sebesar Rp. 7.462.278,- .

Mekanisme perhitungan pajak penghasilan pasal 23 PT. Energy Logistics pada tahun 2015-2016 adalah sebagai berikut

1. PPh pasal 23 Tahun 2015

a. PT. Energy Logistics membayar jasa atasPengiriman Barang kepada PT. Meratus Line dengan nilai jasa sebesar Rp 91.382.926,-

$\mathrm{PPh}$ Pasal 23 yang dipotong oleh PT. Energy Logistics adalah :

$2 \%$ x Rp 91.382.926,- = Rp 1.827.659,-

Maka pembayaran Rp 91.382.926 dari PT. Energy Logistics ke PT. Meratus Line telah dipotong PPh pasal 23 sebesar Rp 1.827.659 sehingga jumlah pembayaran yang harus diterima oleh PT. Meratus Line adalah Rp89.555.267 (+bukti potong PPh pasal 23 sebesar Rp 1.827.659)

b. PT. Energy Logistics menyewa jasaPenyimpanan Barang kepadaPT. Pelindo IVdengan nilai sewa sebesar Rp 128.514.636

PPh Pasal 23 yang dipotong oleh PT. Energy Logistics adalah :

$2 \%$ x Rp 128.514.636,- = Rp 2.570.293,-

Maka pembayaran Rp 128.514.636 dari PT. Energy Logistics ke PT. Pelindo IV telah dipotong PPh pasal 23 sebesar Rp 2.570.293 sehingga jumlah pembayaran yang harus diterima oleh PT. Pelindo IV adalah Rp 125.944.343 (+bukti potong PPh pasal 23 sebesar Rp 128.514.636)

c. PT. Energy Logistics membayar jasa atasPenarikan KapalkepadaPT. Pelindo IVdengan nilai jasa sebesar Rp 111.137.187

PPh Pasal 23 yang dipotong oleh PT. Energy Logistics adalah :

$2 \%$ x Rp 111.137.187,- = Rp 2.222.744,-

Maka pembayaranRp 111.137.187 dari PT. Energy Logistics ke PT. Pelindo IVtelah dipotong PPh pasal 23 sebesarRp 2.222.744sehingga jumlah pembayaran yang harus diterima oleh PT. Pelindo IV adalahRp 108.914.443343 (+bukti potong PPh pasal 23 sebesarRp 2.222.744)

d. PT. Energy Logistics membayar jasa atasCleaningkepadaPT. Lantas Forwarding Indonesiadengan nilai jasa sebesar Rp 109.086.515

PPh Pasal 23 yang dipotong oleh PT. Energy Logistics adalah :

$2 \%$ x Rp 109.086.515,- = Rp 2.181.730,-

Maka pembayaran Rp 109.086.515 dari PT. Energy Logistics ke PT. Lantas Forwarding Indonesiatelah dipotong PPh pasal 23 sebesarRp 2.181.730sehingga jumlah pembayaran yang harus diterima olehPT. Lantas Forwarding Indonesia adalah Rp 106.904.785(+bukti potong PPh pasal 23 sebesarRp 2.181.730)

e. PT. Energy Logistics menyewa jasaPengangkutan Transportasi darat kepada CV. Tirta Rayadengan nilai sewa sebesar Rp 242.386.090

PPh Pasal 23 yang dipotong oleh PT. Energy Logistics adalah :

$2 \%$ x Rp 242.386.090,- = Rp 4.847.722,-

Maka pembayaran Rp 242.386.090 dari PT. Energy Logistics ke CV. Tirta Rayatelah dipotong PPh pasal 23 sebesarRp 4.847.722sehingga jumlah pembayaran yang harus 
diterima olehCV. Tirta Raya adalah Rp 237.538.368(+bukti potong PPh pasal 23 sebesarRp 4.847.722)

f. PT. Energy Logistics membayar jasa atasPerawatan dan Perbaikan kepada PT. Bosowa Berlian Motor dengan nilai jasa sebesar Rp 7.462.278

$\mathrm{PPh}$ Pasal 23 yang dipotong oleh PT. Energy Logistics adalah :

$2 \%$ x Rp 7.462.278,- = Rp 149.246,-

Maka pembayaran Rp 7.462.278 dari PT. Energy Logistics ke PT. Bosowa Berlian Motortelah dipotong PPh pasal 23 sebesarRp 149.246sehingga jumlah pembayaran yang harus diterima olehPT. Bosowa Berlian Motor adalah Rp 7.313.032368(+bukti potong PPh pasal 23 sebesarRp 149.246)

2. PPh Pasal 23 Tahun 2016

a. PT. Energy Logistics membayar jasa atasPenarikan KapalkepadaPT. Pelindo IVdengan nilai jasa sebesar Rp 953.564.758

PPh Pasal 23 yang dipotong oleh PT. Energy Logistics adalah :

2\% x Rp 953.564.758,- = Rp 19.071.295,-

Maka pembayaran Rp 953.564.758 dari PT. Energy Logisticske PT. Pelindo IVtelah dipotong PPh pasal 23 sebesarRp 19.071.295sehingga jumlah pembayaran yang harus diterima oleh PT. Pelindo IV adalah Rp 934.493.463(+bukti potong PPh pasal 23 sebesarRp 19.071.295)

b. PT. Energy Logistics menyewa jasaPenyimpanan Barang kepadaPT. Pelindo IVdengan nilai sewa sebesar Rp 430.125.952

PPh Pasal 23 yang dipotong oleh PT. Energy Logistics adalah :

$2 \%$ x Rp 430.125.952,- = Rp 8.602.519,-

Maka pembayaran Rp 430.125.952 dari PT. Energy Logisticske PT. Pelindo IVtelah dipotong PPh pasal 23 sebesarRp 8.602.519sehingga jumlah pembayaran yang harus diterima oleh PT. Pelindo IV adalahRp 421.523.433463(+bukti potong PPh pasal 23 sebesarRp 8.602.519)

c. PT. Energy Logistics membayar jasa atas Handling kepadaPT. Tunas Karya Agungdengan nilai jasa sebesar Rp 90.089.800

PPh Pasal 23 yang dipotong oleh PT. Energy Logistics adalah :

$2 \%$ x Rp 90.089.800,- = Rp 1.801.796,-

Maka pembayaran Rp 90.089.800 dari PT. Energy LogisticskePT. Tunas Karya Agungtelah dipotong PPh pasal 23 sebesarRp 1.801.796sehingga jumlah pembayaran yang harus diterima olehPT. Tunas Karya Agung adalah Rp 88.288.004(+bukti potong PPh pasal 23 sebesarRp 1.801.796)

d. PT. Energy Logistics membayar jasa atas Pengepakan kepada Angkasa Pura dengan nilai jasa sebesar Rp 387.457.384

PPh Pasal 23 yang dipotong oleh PT. Energy Logistics adalah :

$2 \%$ x Rp 387.457.384,- = Rp 7.749.148,-

Maka pembayaran Rp 387.457.384dari PT. Energy Logisticske Angkasa Pura telah dipotong PPh pasal 23 sebesar Rp 7.749.148 sehingga jumlah pembayaran yang harus diterima oleh Angkasa Pura adalah Rp 379.708.236(+bukti potong PPh pasal 23 sebesar Rp 7.749.148)

e. PT. Energy Logistics membayar jasa atasCleaningkepadaPT. Lantas Forwarding Indonesiadengan nilai jasa sebesar Rp 418.248.939

PPh Pasal 23 yang dipotong oleh PT. Energy Logistics adalah :

$2 \%$ x Rp 418.248.939,- = Rp 8.364.979,-

Maka pembayaran Rp 418.248.939 dari PT. Energy Logistics ke PT. Lantas Fowarding Indonesiatelah dipotong $\mathrm{PPh}$ pasal 23 sebesarRp 8.364.979sehingga jumlah 
pembayaran yang harus diterima olehPT. Lantas Fowarding Indonesia adalah Rp 409.883.960(+bukti potong PPh pasal 23 sebesarRp 8.364.979)

f. PT. Energy Logistics menyewa jasaPengangkutan Transportasi darat kepada PT. Nafra Jaya Mandiri dengan nilai sewa sebesar Rp 241.798.240

$\mathrm{PPh}$ Pasal 23 yang dipotong oleh PT. Energy Logistics adalah :

$2 \%$ x Rp 241.798.240,- = Rp 4.835.965,-

Maka pembayaran Rp 241.798.240 dari PT. Energy Logistics ke PT. Nafra Jaya Mandiritelah dipotong PPh pasal 23 sebesarRp 4.835.965sehingga jumlah pembayaran yang harus diterima olehPT. Nafra Jaya Mandiri adalah Rp 236.962.275(+bukti potong PPh pasal 23 sebesarRp 4.835.965)

g. PT. Energy Logistics menyewa jasa Penyedia Tenaga kerja kepada PT. Vandika Abadidengan nilai sewa sebesar Rp 85.711.905

PPh Pasal 23 yang dipotong oleh PT. Energy Logistics adalah :

$2 \%$ x Rp 85.711.905,- = Rp 1.714.238,-

Maka pembayaran Rp 85.711.905 dari PT. Energy Logistics ke PT. Vandika Abaditelah dipotong PPh pasal 23 sebesarRp 1.714.238sehingga jumlah pembayaran yang harus diterima olehPT. Vandika Abadi adalah Rp 83.997.667(+bukti potong PPh pasal 23 sebesar(+bukti potong PPh pasal 23 sebesarRp 1.714.238)

\section{KESIMPULAN DAN SARAN}

\subsection{Kesimpulan}

Berdasarkan hasil penelitian dan pembahasan yang dilakukan, peneliti menarik kesimpulan sebagai berikut.

1. Pengenaan pajak penghasilan pasal 23 atas jasa freight forwarding pada PT. Energy Logistics cabang Manado telah sesuai dengan Undang-Undang No. 36 tahun 2008.

2. Pelaporan nilai objek pajak $\mathrm{PPh}$ pasal 23atas jasa freight forwardingpadaPT. Energy Logistics cabang Manado telah sesuai dengan Undang-Undang No. 36 tahun 2008

3. PT. Energy Logistics belum memotong PPh pasal 23 dari pembayarannya ke para vendor yang berkerja sama dengannya

\subsection{Saran}

Berdasarkan hasil penelitian maka saran yang perlu dilakukan yaitu:

1. Sebaiknya PT. Energy Logistics harus memotong PPh pasal 23 dari pembayarannya ke para vendor yang berkerja sama dengannya, agar terhindar dari kesalahan pajak yang kerap terjadi.

2. Sebaiknya untuk PT. Energy Logistics mempertahankan tetap melaksanakan pemotongan $\mathrm{PPh} 23$ untuk setiap jasa yang sudah diatur dalam Peraturan Menteri Keuangan No. 244/PMK.03/2008 Tanggal 31 Desember 2008 tentang Jenis Jasa Lain sebagaimana dimaksud dalam Pasal 23 Ayat (1) Huruf c Angka 2 Undang-Undang Nomor 7 Tahun 1983 tentang Pajak Penghasilan sebagaimana telah beberapa kali diubah terakhir dengan Undang-Undang Nomor 36 Tahun 2008 yang berlaku sejak 1 Januari 2009 mengatur bahwa jenis jasa lain yang sama dengan jasa freight forwarding tersebut antara lain adalah jasa perantara atau ke agenan. Maka dari jasa-jasa yang telah diatur tersebut jika dalam transaksi freight forwording tersebut terdapat jasa-jasa yang masuk dalam daftar positif sebaiknya tetap pihak PT. Energy Logistics melakukan pemotongan PPh pasal 23.

3. Diharapkan adanya pembahasan yang lebih mendalam terhadap pajak penghasilan terhadap jasafreight forwarding, maka orang-orang yang bergerak dibidang industri freight forwarding dapat lebih mengerti tentang pengenaan pajakpenghasilan pada jasa freight forwarding, Sehingga dapat memberikan dampak yangsignifikan pada pertumbuhan atau perkembangan bisnis di bidang jasa freight forwarding. 


\section{DAFTAR PUSTAKA}

Aristanti, Widyaningsih. 2012. Hukum Pajak dan Perpajakan. Bandung: ALFABETA

Armstrong, Christopher S. Jennifer L. Blouin. Alan D.Jagolinzer. David F.Larcker. 2015. Corporate Governance, Incentives, and Tax Avoidance. Journal of Accounting and Economics Vol. 60 (2015)1-17

Bahar, A.Aulidya. 2013. Analisis Pajak Penghasilan Pasal 23 Atas Jasa Freight Forwarding Pada PT. Silkargo Cabang Makassar. Skripsi. Universitas Hasanuddin Makassar

Badertscher Brad A. , SharonP.Katz \& SonjaO.Rego.2013. The Separation Of Ownership And Control And Corporate Tax Avoidance. International Journal of Accountingand Economics56(2013)228-250

Boone, Khurana, Raman. 2013. Religiosity and Tax Avoidance. Journal Of American Taxation Association Volume 35 issues 1 pages 53-84

Harnanto. 2013. Perencanaan Pajak, Edisi Pertama,Penerbit BPFE. Yogyakarta

Hendra, 2014. Analisis Perhitungan Pajak Penghasilan Pasal 23 Pada PT. Golden Mitra Inti Perkasa. Skripsi. Universitas Sam Ratulangi

Ismail, Shinta. 2014. Analisis Perhitungan, Penyetoran Dan Pelaporan Pajak Penghasilan Pasal 25 Pada CV Delta Dharma. Skripsi. Universitas Sam Ratulangi

Jusuf, Vivi S. 2013. Penerapan Akuntansi Terhadap Pajak Penghasilan Pasal 25 Pada PT. Sinar Pacifik Internusa Manado. Skripsi. Universitas Sam Ratulangi

Kieso, Jerry Weygandt, Terry Warfield, 2010. Financial Accounting. IFRS Edition. Penerbit WILEY. Hoboken New Jersey

Limas, Sally Martina. 2012. Analisis Akuntansi Pph Pasal 22, Pph Pasal 23, Dan Ppn Di PT. Terminal Petikemas Surabaya. Skripsi. Universitas KatolikWidya Mandala Surabaya

Ilyas, Wirawan \& Burton, Richard. 2013. Hukum Pajak, Cetakan Kedua, Penerbit Salemba Empat, Jakarta

Mardiasmo. 2013. Perpajakan Edisi Revisi. Penerbit Andi. Yogyakarta

Muljono, Djoko. 2012. Akuntansi Pajak dan Ketentuan Umum Perpajakan. Penerbit Andi, Yogyakarta

Muljono, Djoko \& Wicaksono, Baruni 2012. Akuntansi Pajak Lanjutan. Penerbit Andi, Yogyakarta

Nelwan, Tirsa SW, 2013. Evaluasi Pemotongan, Penyetoran Dan Pelaporan Pph Pasal 23 Pada Bank Prisma Dana Manado. Skripsi. Universitas Sam Ratulangi

Silitonga, Laorens. 2013. Penerapan Tax Planning Atas Pajak Penghasilan Badan Pada Cv. Andi Offset Cabang Manado. Skripsi. Universitas Sam Ratulangi 